\title{
The role of mast cells in lymphangiogenesis in psoriasis
}

\author{
Rola komórek tucznych w lymfangiogenezie w łuszczycy
}

Ahmed Abdel-Bary', Amany Abdel-Bary²

'Department of Dermatology, Venereology and Andrology, Faculty of Medicine, Alexandria University, Alexandria, Egypt 2Department of Pathology, Faculty of Medicine, Alexandria University, Alexandria, Egypt

Dermatol Rev/Przegl Dermatol 2020, 107, 495-507

DOI: https://doi.org/I0.5 | |4/dr.2020. 103886

CORRESPONDING AUTHOR/ ADRES DO KORESPONDENCJI:

Ahmed Abdel-Bary MD

Department of Dermatology,

Venereology and Andrology

Faculty of Medicine

Alexandria University

Alexandria, Egypt

e-mail: drahmedabdelbary2016@

gmail.com

\begin{abstract}
Introduction. Lymphangiogenesis is a complex process mediated by a wide spectrum of inflammatory cells including mast cells. Lymphatic vessels play an important role in chronic inflammatory disorders including psoriasis.

Objective. Assessment of interaction between lymphatic vessels and inflammatory cells, including mast cells to determine the influence of inflammatory cells on lymphangiogenesis in psoriasis.
\end{abstract}

Material and methods. Fifty patients with psoriasis and 10 healthy controls were included. D2-40 immunostaining was performed for delineation of lymphatic vessels, and Giemsa stain for highlighting mast cells.

Results. Psoriatic skin lesions were characterized by a higher number of mast cells and inflammatory cells as well as denser and larger lymphatic vessels than normal skin. A significant positive correlation was detected between number of lymphatic vessels and mast cells as well as other inflammatory cells in psoriatic lesions. However, none of them emerged as an independent inducer of lymphangiogenesis on multilogistic regression analysis. Simple logistic regression analysis revealed that mast cells are significant influencers. One unit change in mast cells can explain 1.369 unit changes in lymphatic vessels, while one unit change in other inflammatory cells can only explain 0.099 unit change in lymphatic vessels.

Conclusions. Mast cells and other inflammatory cells significantly and synergistically act in induction of lymphangiogenesis in psoriatic lesions, with a slightly higher participation for mast cells.

\section{STRESZCZENIE}

Wprowadzenie. Limfangiogeneza jest złożonym procesem, w którym uczestniczy szerokie spektrum komórek zapalnych, w tym komórki tuczne. Naczynia limfatyczne odgrywają istotną rolę w przewlekłych chorobach zapalnych, m.in. w łuszczycy.

Cel pracy. Ocena interakcji pomiędzy naczyniami limfatycznymi a komórkami zapalnymi, w tym komórkami tucznymi, w celu określenia wpływu komórek zapalnych na proces limfangiogenezy w łuszczycy.

Materiał i metody. Badanie objęło 50 pacjentów z łuszczycą i 10 zdrowych osób, które stanowiły grupe kontrolną. Do wizualizacji naczyń limfatycznych wykorzystano barwienie immunohistochemiczne z przeciwciałem D2-40, a do oznaczenia komórek tucznych - barwienie metodą Giemsy. 
Wyniki. W łuszczycowych zmianach skórnych wykazano znamiennie większą ekspresję liczby komórek tucznych i komórek zapalnych, a także stwierdzono większą gęstość i rozmiar naczyń limfatycznych niż w zdrowej skórze. Uzyskano znamienną dodatnią korelację między liczbą naczyń limfatycznych a liczbą komórek tucznych oraz innymi komórkami zapalnymi w zmianach łuszczycowych. W analizie opartej na wielomianowej regresji logistycznej nie stwierdzono jednak, aby którykolwiek z powyższych czynników stanowił niezależny czynnik indukujący limfangiogenezę. Analiza regresji logistycznej jednowymiarowej wykazała, że komórki tuczne są istotnym czynnikiem indukującym. Pojedyncza zmiana jednostkowa w komórkach tucznych może odpowiadać za 1369 zmian jednostkowych w naczyniach limfatycznych. Dla porównania - pojedyncza zmiana jednostkowa w pozostałych komórkach zapalnych może wyjaśniać zaledwie 0,099 zmiany jednostkowej w naczyniach limfatycznych.

Wnioski. Komórki tuczne i inne komórki zapalne mają znamienny oraz synergistyczny wpływ na indukcję limfangiogenezy w zmianach łuszczycowych, przy czym wiodącą rolę w tym procesie odgrywają komórki tuczne.

Key words: psoriasis, lymphangiogenesis, mast cells.

Słowa kluczowe: łuszczyca, limfangiogeneza, komórki tuczne.

\section{INTRODUCTION}

Psoriasis is a common inflammatory skin disease affecting between $0.09 \%$ and $11.4 \%$ of the general population worldwide $[1,2]$. The definite pathogenesis of psoriasis is not precisely known, but the role of immunological and genetic influences in the development of chronic inflammation in psoriatic skin is clear [3]. The main histopathological features of psoriasis include parakeratosis, reduced granular layer, regular epidermal hyperplasia, epidermal infiltration by neutrophils, mononuclear dermal inflammatory infiltrate and dilated tortuous vascular spaces in dermal papillae [4]. The changes in the dermal vasculature represent one of the early histopathological features in psoriasis. This attracts attention to the role of angiogenesis and lymphangiogenesis in the pathogenesis of this disease [5]. Lymphangiogenesis plays an important role in inflammatory disorders. It is responsible for antigen clearance, drainage of excessive interstitial fluid and recruitment of immune cells. For this reason, lymphangiogenesis may have a role in resolution of inflammation [6]. Mast cells are not only involved in type I allergic reaction but also participate in the pathogenesis of chronic inflammatory disorders through the release of different mediators [7]. Moreover, mast cells are sources and targets

\section{WPROWADZENIE}

Łuszczyca jest powszechną chorobą zapalną skóry, która dotyka 0,09-11,4\% światowej populacji [1, 2]. Jej patogeneza nie jest dokładnie poznana, ale potwierdzono rolę czynników immunologicznych i genetycznych w rozwoju przewlekłego stanu zapalnego w skórze zajętej przez zmiany łuszczycowe [3]. Główne cechy histopatologiczne łuszczycy to parakeratoza, zanik warstwy ziarnistej naskórka, przerost naskórka, naciekanie naskórka przez neutrofile, a także obecność nacieków zapalnych z komórek jednojądrzastych w skórze i poszerzonych, krętych naczyniach w brodawkach skóry [4]. Zmiany w układzie naczyniowym skóry stanowią jedną z wczesnych cech histopatologicznych łuszczycy. Zwraca to uwage na rolę angiogenezy i limfangiogenezy w patogenezie tej choroby [5]. Limfangiogeneza odgrywa istotną rolę w chorobach zapalnych. Odpowiada za klirens antygenowy, drenaż nadmiaru płynu śródmiąższowego i rekrutację komórek odpornościowych. Z tego powodu limfangiogeneza może odgrywać rolę w eliminacji stanu zapalnego [6]. Komórki tuczne biorą udział nie tylko w reakcji alergicznej typu I, lecz także w patogenezie przewlekłych zaburzeń zapalnych poprzez uwalnianie różnych mediatorów [7]. Oprócz tego komórki tuczne są źródłem i miejscem docelowym 
of angiogenic and lymphangiogenic factors such as vascular endothelial growth factors (VEGF) A, B, C, and D [8]. Angiogenesis and lymphangiogenesis are also stimulated by inflammatory cells other than mast cells, including neutrophils, macrophages and Th17 lymphocytes. These cells are well-known participators in the pathogenesis of psoriasis [9]. Although essential in mediating inflammation, the exact interaction between mast cells and lymphangiogenesis has remained unexplored in psoriasis vulgaris.

\section{OBJECTIVE}

The aim of this study was to evaluate the relation between lymphatic vessels and inflammatory cells including mast cells in psoriasis vulgaris, and finally to determine which cells can independently induce lymphangiogenesis in this common inflammatory disease.

\section{MATERIAL AND METHODS}

Fifty newly diagnosed patients with the classical picture of psoriasis vulgaris were selected for this study from the Outpatient Clinic of the Dermatology and Venereology Department, Alexandria Main University Hospital, Egypt, during the period between June 2017 and June 2018.

Clinical assessment of psoriatic patients was performed through calculation of the Psoriatic Area and Severity Index (PASI score).

Patient's consent was taken and the study was approved by the local Ethics Committee at the Faculty of Medicine, University of Alexandria, Egypt.

\section{Histopathological examination}

An incisional biopsy was harvested from one of the psoriatic lesions of each patient, in addition to 10 normal skin biopsies (taken from normal skin excised from breast reduction surgical specimens done for cosmetic purposes) which were included in the study as a control.

Five-micron thick sections were cut from the formalin-fixed, paraffin-embedded blocks of the skin biopsies, stained with H\&E then examined by light microscopy for confirmation of the clinical diagnosis and for grading of dermal lymphocytic inflammation using a semiquantitative three graded score: grade 1: mild, grade 2: moderate and grade 3: severe [10].

\section{Giemsa staining}

Five-micron thick blank sections were prepared from each block and stained with Giemsa stain for identification of mast cells. Sections were deparaf- dla czynników angiogennych i limfangiogennych, takich jak czynniki wzrostu śródbłonka naczyniowego (vascular endothelial growth factors - VEGF) A, B, C i D [8]. Procesy angiogenezy i limfangiogenezy ulegają pobudzeniu nie tylko przez komórki tuczne, lecz także komórki zapalne (neutrofile, makrofagi i limfocyty Th17). Udział tych komórek w patogenezie łuszczycy jest powszechnie znany [9]. Mimo że odgrywają one kluczową rolę pośredniczącą w stanach zapalnych, dokładne zależności pomiędzy komórkami tucznymi a procesem limfangiogenezy w łuszczycy nie są znane.

\section{CEL PRACY}

Celem pracy była ocena zależności pomiędzy limfangiogenezą i komórkami zapalnymi, m.in. komórkami tucznymi, w łuszczycy zwyczajnej. Kolejnym celem było ustalenie, które komórki mogą w sposób niezależny wywoływać limfangiogenezę w przebiegu tej powszechnie występującej choroby zapalnej.

\section{MATERIAŁ I METODY}

Do badania włączono 50 pacjentów z nowo rozpoznaną łuszczycą (psoriasis vulgaris), którzy zgłosili się do poradni Kliniki Dermatologii i Wenerologii Szpitala Uniwersyteckiego w Aleksandrii (Egipt). Badanie obejmowało okres od czerwca 2017 r. do czerwca 2018 r.

W ocenie klinicznej u chorych obliczono stopień zajęcia powierzchni skóry przez zmiany łuszczycowe, a także wskaźnik (Psoriatic Area and Severity Index - PASI).

Od pacjentów uzyskano świadomą zgodę na udział. Badanie zostało zatwierdzone przez komisję bioetyczną przy Wydziale Medycyny Uniwersytetu Aleksandryjskiego w Egipcie.

\section{Badanie histopatologiczne}

U każdego uczestnika wykonano biopsję z jednej ze zmian łuszczycowych. Oprócz tego do analizy włączono 10 wycinków skóry zdrowej (pochodzących z materiału chirurgicznego uzyskanego podczas operacji plastycznych redukcji piersi) jako próbę kontrolną.

$\mathrm{Z}$ utrwalonych $\mathrm{w}$ formalinie i zatopionych $\mathrm{w}$ parafinie bloczków zawierających materiał z biopsji skóry wycięto skrawki o grubości 5 mikronów. Wybarwiono metodą H\&E, a następnie zbadano pod mikroskopem świetlnym w celu potwierdzenia rozpoznania klinicznego i oceny stopnia nasilenia limfocytarnego zapalenia skóry przy wykorzystaniu półilościowej trójstopniowej skali: stopień 1 - nasilenie łagodne, stopień 2 - umiarkowane, stopień 3 - ciężkie [10]. 
finized and hydrated in distilled water, then the slides were placed in a staining tray and flooded with working May-Grünwald-Giemsa solution. The slides were then differentiated by dipping them in acetic acid solution $(0.25 \%)$ until desired background intensity was reached and lastly they were dehydrated, cleared, and mounted [11].

\section{Counting the number of mast cells and other inflammatory cells}

The slides were examined by light microscopy and mast cells were identified by their purple metachromatic granules. The mean number of Giemsa +ve mast cells/high power field (HPF) and the mean number of Giemsa -ve inflammatory cells were counted in the same fields using the hot spot method [12]. The number of mast cells was also counted in the control.

Giemsa-stained sections were screened at low power $(10 \times)$ for detection of the area of highest staining (the hot spot) and 10 random non-overlapping fields were chosen within the hot area at magnifications of $400 \times$. The number of mast cells (positively stained for Giemsa) was counted in the 10 fields then the mean number/HPF was calculated. Similarly, the mean number of other inflammatory cells (negatively stained for Giemsa)/HPF was calculated. The total number of cells was finally calculated (mast cells + other inflammatory cells).

\section{Immunohistochemical staining}

Immunostaining was performed using the avidinbiotinylated immune-peroxidase method. The detection system was provided by Lab Vision Corporation (Neo Markers, Fremont, USA). The primary antibody D2-40 (Rabbit monoclonal antibody, clone SP6) (Thermo Scientific Lab Vision, USA) was used.

The deparaffinized tissue sections were rehydrated in graded alcohols. The endogenous peroxidase was blocked using $0.3 \%$ hydrogen peroxide for $20 \mathrm{~min}$. For antigen retrieval, sections were microwaved in a thermoresistant container (Coplin jar) containing citrate $(10 \mathrm{mM}, \mathrm{pH} 6.0)$. The primary antibody was then applied at a concentration of $1: 100$. The reaction product was developed using diaminobenzidine tetrahydrochloride (DAB) mixture for ten minutes. The DAB mixture was freshly prepared for each run (for each slide: $2 \mu$ l of DAB chromogen added to $100 \mu \mathrm{l}$ of DAB substrate). Slides were counterstained with hematoxylin, dehydrated and mounted.

The mean number of lymphatic vessels was evaluated in D2-40 stained sections of the cases and control using a semiquantitative technique [13]. In each $\mathrm{HPF}$, the diameter of the vessels was measured using

\section{Barwienie metodą Giemsy}

Z każdego bloczku wykrojono skrawki o grubości 5 mikronów i wybarwiono je metodą Giemsy w celu identyfikacji komórek tucznych. Skrawki odparafinowano i uwodniono w wodzie destylowanej. Następnie szkiełka umieszczono $\mathrm{w}$ kuwecie do barwienia i zalano aktywnym roztworem barwnika do metody Maya-Grünwalda-Giemsy. Różnicowanie przeprowadzono poprzez zanurzenie preparatów w roztworze kwasu octowego $(0,25 \%)$ aż do uzyskania pożądanego natężenia tła. Na koniec preparaty odwodniono, oczyszczono i osadzono [11].

\section{Liczenie komórek tucznych i innych komórek zapalnych}

Preparaty poddano analizie pod mikroskopem świetlnym. Komórki tuczne zidentyfikowano na podstawie obecności charakterystycznych metachromatycznych, fioletowych ziarnistości. Średnią liczbę komórek tucznych wybarwionych dodatnio (+) metodą Giemsy w polu widzenia (wpw) i średnią liczbę komórek zapalnych wybarwionych ujemnie (-) metodą Giemsy zliczono w tych samych polach, stosując metodę hot spot [12]. Liczbę komórek tucznych oznaczono także w preparatach stanowiących grupę kontrolną.

Preparaty wybarwione metodą Giemsy poddano analizie przesiewowej przy małym powiększeniu (10×) w celu wykrycia obszaru o najbardziej intensywnym wybarwieniu (tzw. hot spotu). Następnie wybrano 10 losowych, niepokrywających się pól w obrębie obszaru hot spot przy powiększeniu 400×. Liczbę komórek tucznych (wybarwionych (+) metodą Giemsy) zliczono w 10 polach, a następnie obliczono ich średnią liczbę wpw. Analogicznie obliczono średnią liczbę pozostałych komórek zapalnych (wybarwionych (-) metodą Giemsy) wpw. Następnie wyliczono całkowitą liczbę komórek (komórki tuczne plus inne komórki zapalne).

\section{Barwienie immunohistochemiczne}

Immunobarwienie przeprowadzono z zastosowaniem kompleksu awidyna-biotynylowana peroksydaza. Wykorzystano system detekcji firmy Lab Vision Corporation (Neo Markers, Fremont, USA). Zastosowano przeciwciało pierwszorzędowe D2-40 (królicze przeciwciało monoklonalne, klon SP6) (Thermo Scientific Lab Vision, USA).

Odparafinowane skrawki tkanki ponownie uwodniono we wzrastających stężeniach alkoholu. Endogenną peroksydazę blokowano nadtlenkiem wodoru 0,3\% przez 20 minut. Skrawki poddano działaniu mikrofal w termoodpornym naczyniu (barwiaczu Coplina) wypełnionym cytrynianem $(10 \mathrm{mM} ; \mathrm{pH} 6,0)$. Następnie zastosowano przeciwciało pierwszorzędowe w stężeniu $1: 100$. Reakcję wywoływano przy wykorzystaniu mieszaniny czterochlorowodorku diaminobenzydyny (DAB) przez 10 minut. Mieszaninę DAB 
a calibrated lens, then the mean vessel diameter was calculated per HPF.

\section{Statistical analysis}

Data were analyzed using Statistical Package for Social Sciences (SPSS ver. 20, Chicago, IL, USA).

The Spearman rank correlation test was used for correlation between quantitative variables.

The Monte Carlo significance test was used for correlation between qualitative variables. The oneway ANOVA test was used for comparison between quantitative and qualitative variables. The multiple logistic regression model was done using the enter method for the contribution to number of lymphatic vessels (significant variables by univariate analysis were entered and variables causing multicollinearity problems were excluded). The model was assessed using Nagelkerke $\mathrm{R}^{2}$ and odds ratio with 95\% CI.

In all statistical tests, the level of significance of 0.05 was used, below which the results were considered to be statistically significant $(p<0.05)$.

\section{RESULTS}

Fifty patients affected by psoriasis vulgaris were included in the study. The age of the patients ranged from 21 to 79 years with a mean of $53.6 \pm 15.8$ years. Thirty-two (64\%) patients were male and 18 (36\%) were female. PASI score ranged between 8 and 27.6 with a mean of $17.1 \pm 5$ and a median range of 16.8 .

\section{Histopathological examination}

Incisional skin biopsies of the fifty studied cases of psoriasis shared the following histological features with variable degrees of severity: acanthosis with uniform elongation of the rete ridges, parakeratosis, loss of the granular cell layer, as well as dilated tortuous capillaries in the papillary dermis with perivascular inflammatory infiltrate formed mainly of lymphocytes.

\section{Giemsa staining}

Giemsa stain delineated the mast cells in psoriatic skin lesions and in the normal skin as spindled or oval shaped cells with characteristic purple metachromatic granules. Mast cells were retrieved throughout the dermis as well as in the papillary dermis with perivascular condensation. The mean number of mast cells was significantly higher in psoriatic skin $(8.3 \pm 4)$ than in normal skin $(1.8 \pm 0.8)\left(p<0.001^{*}\right)$ (fig. 1$)$.

\section{Inflammatory cells}

The number of Giemsa -ve inflammatory cells in biopsies of the psoriatic lesions ranged from 60 to 300 przygotowywano na świeżo dla każdego przebiegu (dla każdego szkiełka wprowadzono $2 \mu$ l chromogenu DAB do $100 \mu$ l substratu DAB). Szkiełka wybarwiano kontrastowo hematoksyliną, a następnie odwadniano i osadzano.

Średnią liczbę naczyń limfatycznych oceniano metodą półilościową w preparatach wybarwionych D2-40 zarówno w grupie badanej, jak i kontrolnej [13]. W każdym polu widzenia mierzono średnicę naczyń przy wykorzystaniu skalibrowanej soczewki, a następnie obliczano średnią średnicę naczyń wpw.

\section{Analiza statystyczna}

Dane analizowano przy wykorzystaniu oprogramowania Statistical Package for Social Sciences (SPSS wer. 20, Chicago, IL, USA).

Do oceny korelacji między zmiennymi ilościowymi zastosowano test korelacji rang Spearmana. Przy ocenie korelacji między zmiennymi jakościowymi wykorzystano test istotności Monte Carlo. Porównanie zmiennych ilościowych i jakościowych przeprowadzono przy zastosowaniu jednokierunkowego testu ANOVA. Opracowano model wielokrotnej regresji logistycznej z wykorzystaniem metody enter w celu oceny wpływu na liczbę naczyń limfatycznych (włączono istotne zmienne $\mathrm{z}$ analizy jednowymiarowej i wykluczono zmienne wywołujące problemy ze współliniowością). Ocenę modelu przeprowadzono, stosując współczynnik $\mathrm{R}^{2}$ Nagelkerke'a i iloraz szans na poziomie ufności 95\% CI.

We wszystkich obliczeniach statystycznych jako poziom istotności przyjęto 0,05. Poniżej tej wartości wyniki uznano za znamienne statystycznie $(p<0,05)$.

\section{WYNIKI}

W badaniu uczestniczyło 50 pacjentów z łuszczycą zwykłą w wieku od 21 do 79 lat (średnio: 53,6 $6 \pm 15,8$ roku). Badana grupa obejmowała 32 (64\%) mężczyzn i 18 (36\%) kobiet. Wartości wskaźnika PASI mieściły się w przedziale od 8 do 27,6 . Średnia wyniosła $17,1 \pm 5$, a mediana 16,8 .

\section{Badanie histopatologiczne}

$\mathrm{W}$ materiale pozyskanym $\mathrm{z}$ biopsji w 50 badanych przypadkach łuszczycy stwierdzono następujące cechy histologiczne o różnym stopniu nasilenia: akantozę z równomiernym wydłużeniem sopli naskórkowych, parakeratozę, zanik warstwy ziarnistej naskórka, a także obecność poszerzonych, krętych naczyń włosowatych w warstwie brodawkowatej skóry właściwej z okołonaczyniowym naciekiem zapalnym zawierającym głównie limfocyty.

\section{Barwienie metodą Giemsy}

Metodą Giemsy zidentyfikowano komórki tuczne w łuszczycowych zmianach skórnych i zdrowej skó- 
cells/HPF, with a mean number of $162.98 \pm 71.92$. The total number of inflammatory cells ranged from 64 to 315 cells/HPF, with a mean number of $171.06 \pm 74.49$. Twenty-six (52\%) cases were graded as grade 2 (moderate) inflammations, and 24 (48\%) cases were graded as grade 3 (severe) inflammation.

\section{Lymphatic vessels}

D2-40 immunostaining delineated the lymphatic vessels in biopsies of the psoriatic lesions and in the normal skin. In psoriatic lesions the vessels were dilated and tortuous and were seen more in the papillary dermis and decreased gradually in the deep dermis. The mean number of lymphatic vessels was significantly higher in psoriatic skin $(12.8 \pm 7.65)$ than in normal skin $(4.2 \pm 0.4)\left(p<0.001^{*}\right)$. Moreover, the mean diameter of the lymphatic vessels was significantly higher in psoriatic skin $(0.12 \pm 0.07)$ than in normal skin $(0.06 \pm 0.02)$ ( $p=0.003)$ (fig. 2).

\section{Results of univariate statistical analysis}

The mean number of mast cells/HPF significantly correlated with the number of Giemsa -ve inflammatory cells, the total number of inflammatory cells and the inflammatory grade $(p<0.001$ for all).

The mean number of lymphatic vessels significantly correlated with the number of mast cells, the number of inflammatory cells, the total number of cells and the inflammatory grade $(p<0.001$ for all).

No significant correlation was detected between the vessel diameter and number of mast cells, number of inflammatory cells, total number of cells, inflammatory grade or number of lymphatic vessels ( $p=0.418,0.893,0.941,0.548$ and 0.987 respectively).

PASI score significantly increased with increasing grade of inflammation $(p=0.028)$, but no significant correlation was detected between PASI score and number of mast cells, number of inflammatory cells, total number of inflammatory cells or number of lymphatic vessels $(p=0.058,0.460,0.656$ and 0.955 respectively) (fig. 3).

\section{Results of multivariate statistical analysis}

For evaluation of the precise contribution of inflammatory cells in inducing lymphangiogenesis, a multiple logistic regression model was built including mean number of lymphatic vessels and the variables found to be significantly associated with it in univariate analysis. Those variables included mean number of Giemsa +ve mast cells, Giemsa -ve inflammatory cells and the total number of inflammatory cells. The model was not significant and no independent variable that can control lymphangiogenesis emerged ( $p=0.214,0.974$ and 0.798 respectively). rze. Komórki miały postać wrzecionowatą lub owalną, z obecnością charakterystycznych metachromatycznych, fioletowych ziarnistości. Komórki tuczne uwidoczniono w całej skórze właściwej, jak również w warstwie brodawkowatej, z koncentracją okołonaczyniową. Średnia liczba komórek tucznych była znamiennie wyższa w skórze łuszczycowej $(8,3 \pm 4)$ niż w skórze zdrowej $(1,8 \pm 0,8)(p<0,001)$ (ryc. 1$)$.

\section{Komórki zapalne}

Liczba komórek zapalnych wybarwionych (-) metodą Giemsy w preparatach biopsyjnych ze zmian skórnych wahała się od 60 do 300 komórek wpw (średnio: 162,98 $\pm 71,92$ ). Całkowita liczba komórek zapalnych mieściła się w przedziale od 64 do 315 komórek wpw, a średnia liczba wyniosła 171,06 $\pm 74,49$. W 26 (52\%) przypadkach stwierdzono stan zapalny o stopniu nasilenia 2 (umiarkowanym), a w 24 (48\%) przypadkach stan zapalny o stopniu nasilenia 3 (ciężkim).

\section{Naczynia limfatyczne}

Naczynia limfatyczne w materiale biopsyjnym pobranym ze zmian łuszczycowych i zdrowej skóry uwidoczniono metodą immunohistochemiczną z wykorzystaniem przeciwciała D2-40. Naczynia limfatyczne w obrębie zmian łuszczycowych były rozszerzone i miały kręty przebieg. Były bardziej widoczne w warstwie brodawkowatej skóry właściwej, natomiast w głębszych warstwach skóry właściwej ich ilość ulegała zmniejszeniu. Średnia liczba naczyń limfatycznych była znamiennie wyższa w skórze łuszczycowej $(12,8 \pm 7,65)$ niż w skórze zdrowej $(4,2 \pm 0,4)$ $(p<0,001)$. Ponadto w skórze łuszczycowej wykazano znamiennie większą średnią średnicę naczyń limfatycznych $(0,12 \pm 0,07)$ niż w skórze zdrowej $(0,06 \pm 0,02)$ $(p=0,003)$ (ryc. 2).

\section{Wyniki jednowymiarowej analizy statystycznej}

Średnia liczba komórek tucznych wpw istotnie korelowała z liczbą komórek zapalnych wybarwionych (-) metodą Giemsy, całkowitą liczbą komórek zapalnych oraz nasileniem zapalenia (wartość $p<0,001$ dla wszystkich parametrów).

Dla średniej liczby naczyń limfatycznych odnotowano znamienną korelację z liczbą komórek tucznych, liczbą komórek zapalnych, całkowitą liczbą komórek oraz nasileniem zapalenia (wartość $p<0,001$ dla wszystkich parametrów).

Nie stwierdzono znamiennej korelacji pomiędzy średnicą naczyń i liczbą komórek tucznych, liczbą komórek zapalnych, całkowitą liczbą komórek, nasileniem zapalenia i liczbą naczyń limfatycznych (odpowiednio $p=0,418 ; 0,893 ; 0,941 ; 0,548$ i 0,987).

Wartość wskaźnika PASI zwiększała się znamiennie wraz ze wzrostem stopnia stanu zapalnego 

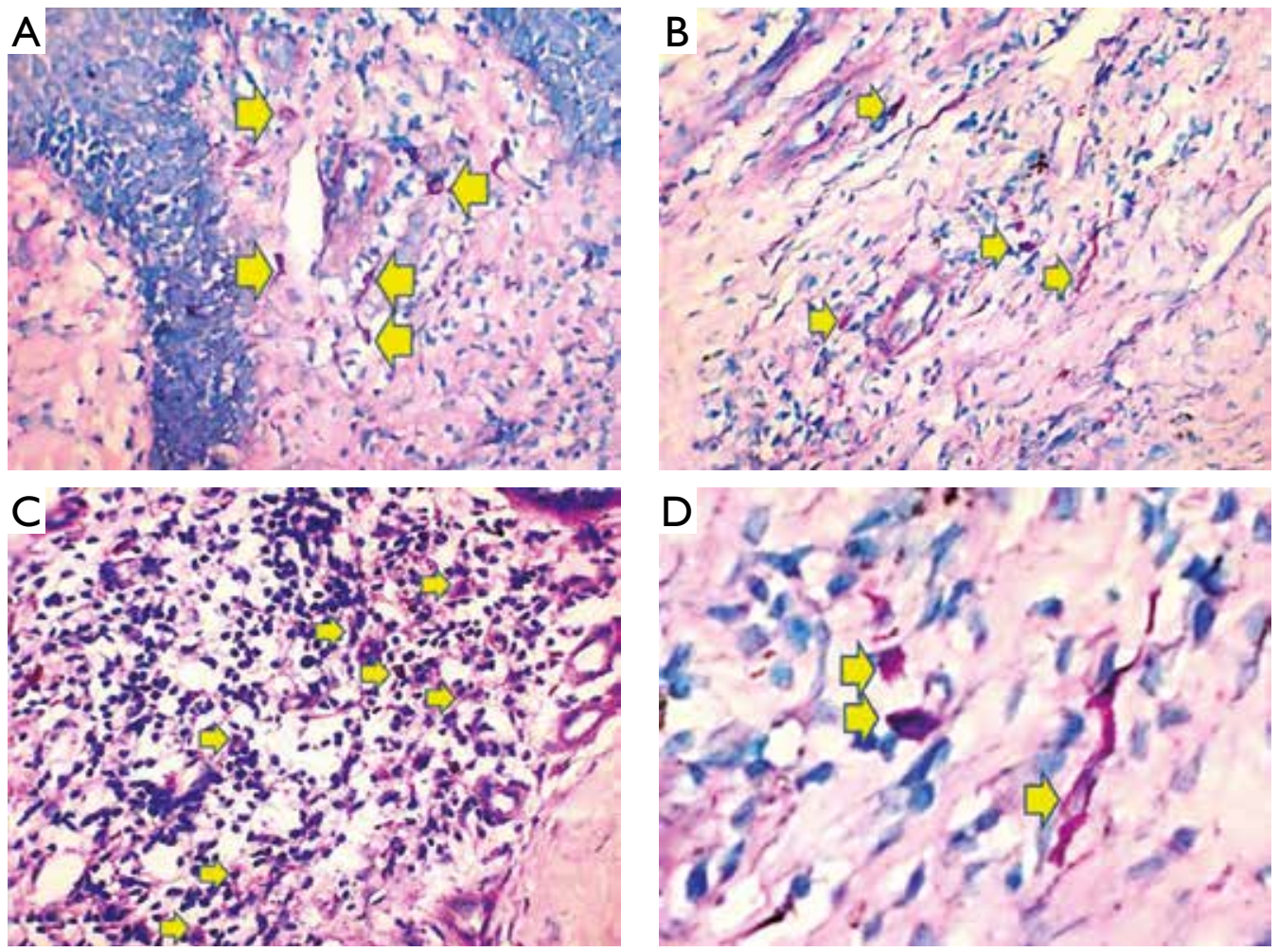

Figure I. Histopathological picture of psoriasis vulgaris after Giemsa staining for delineation of mast cells (arrows). A - Mast cells are seen within the papillary dermis mainly in the perivascular areas (400X). B - Mast cells are seen around the blood vessels in the reticular dermis $(400 \times)$. C - Dense inflammatory infiltrate entangles very numerous mast cells (400X). D - Rounded and spindled mast cells showing purple stained cytoplasmic granules (I000X)

Rycina I. Obraz histopatologiczny łuszczycy zwykłej po wybarwieniu metodą Giemsy w celu identyfikacji komórek tucznych (strzałki). A - Komórki tuczne widoczne w obrębie warstwy brodawkowatej skóry, głównie okołonaczyniowo (400x). B - Komórki tuczne widoczne wokół naczyń krwionośnych w warstwie siateczkowatej skóry właściwej (400×). C - Gęsty naciek zapalny otaczający bardzo liczne komórki tuczne $(400 \times)$. D - Zaokrąglone i wrzecionowate komórki tuczne widoczne jako zabarwione na fioletowo ziarnistości w cytoplazmie (I000x)

However, simple logistic regression model testing revealed that mast cells have a stronger influence in guiding lymphangiogenesis. One unit change in mast cells can explain 1.369 unit changes in lymphatic vessels, while one unit change in other inflammatory cells can only explain 0.099 unit change in lymphatic vessels (table 1).

In the scatter diagram used for presenting the positive linear correlation between the mean number of mast cells and the mean number of lymphatic vessels, two outliers were spotted. The first one was for a case showing the highest number of lymphatic vessels (32/HPF) but with a moderate number of mast cells $(10 / \mathrm{HPFs})$, but this case showed the highest number of Giemsa -ve inflammatory cells in the studied cases. The other outlier was for a case with high number of mast cells $(15 / \mathrm{HPFs})$ but with low number of lymphatic vessels $(8 / \mathrm{HPFs})$, but those vessels had the largest vessel diameter encountered in our study (0.25 mm) (fig. 4). $(p=0,028)$, jednak nie stwierdzono znamiennej korelacji między wskaźnikiem PASI i liczbą komórek tucznych, liczbą komórek zapalnych, całkowitą liczbą komórek zapalnych oraz liczbą naczyń limfatycznych $(p=0,058 ; 0,460 ; 0,656$ i 0,955$)$ (ryc. 3 ).

\section{Wyniki wielowymiarowej analizy statystycznej}

W celu dokładnej oceny wpływu komórek zapalnych na indukcję limfangiogenezy, opracowano model wielokrotnej regresji logistycznej obejmujący średnią liczbę naczyń limfatycznych. Na podstawie analizy jednowymiarowej potwierdzono znamienne oddziaływanie zmiennych. Zmienne te obejmowały średnią liczbę komórek tucznych wybarwionych $(+)$ metodą Giemsy, komórek zapalnych wybarwionych (-) metodą Giemsy oraz całkowitą liczbę komórek zapalnych. W modelu nie stwierdzono znamienności, a żaden $\mathrm{z}$ analizowanych czynników nie stanowił zmiennej niezależnej, która mogłaby dominować $\mathrm{w}$ procesie limfangiogenezy (odpowiednio $p=0,214 ; 0,974 \mathrm{i} 0,798$ ).

W modelu prostej regresji logistycznej wykazano jednak, że komórki tuczne wywierają nieco większy wpływ 

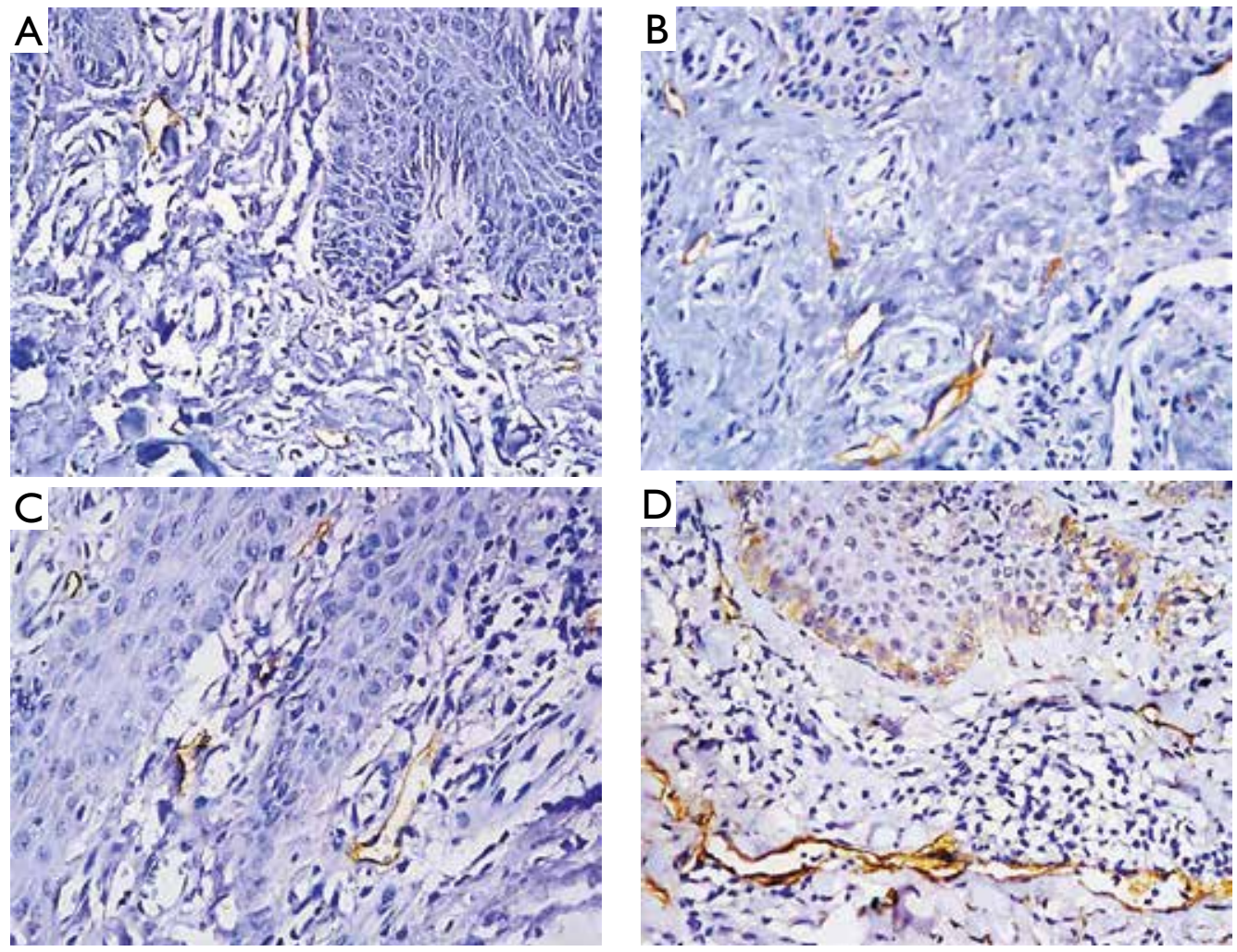

Figure 2. D2-40 immunostaining (400×). A - Normal skin showing scattered lymphatic vessels in papillary and reticular dermis. B - A picture of psoriasis vulgaris showing dermal lymphatic vessels in the papillary dermis with mild inflammatory infiltrate. $\mathbf{C}-\mathrm{A}$ picture of psoriasis vulgaris showing larger sized lymphatic vessels in the papillary dermis associated with moderate inflammation. $\mathrm{D}-\mathrm{A}$ picture of psoriasis vulgaris showing a dense anastomosing network of large lymphatic vessels associated with marked inflammation

Rycina 2. Immunobarwienie D2-40 (400×). A - Zdrowa skóra z rozproszonymi naczyniami limfatycznymi w warstwie brodawkowatej i siateczkowatej. B - Obraz łuszczycy zwykłej z widocznymi naczyniami limfatycznymi w warstwie brodawkowatej skóry właściwej i łagodnym naciekiem zapalnym. C - Obraz łuszczycy zwykłej z widocznymi poszerzonymi naczyniami limfatycznymi w warstwie brodawkowatej skóry właściwej i średnio nasilonym naciekiem zapalnym. D - Obraz łuszczycy zwykłej z widoczną gęstą siecią zespalających dużych naczyń limfatycznych i nasilonym stanem zapalnym

\section{DISCUSSION}

Lymphatic vessels are involved in the pathogenesis of chronic inflammatory skin diseases including psoriasis [14]. Lymphangiogenesis in psoriasis is a complex and multifactorial process, several cells being involved, including mast cells. The inflammatory milieu, namely macrophages, lymphocytes and neutrophils, participates as well to a certain degree in lymphangiogenesis [15-17].

In our study the mean number of Giemsa +ve mast cells significantly increased in psoriatic skin lesions in comparison to the normal skin. Increased number of mast cells in the superficial dermis of lesional psoriatic skin compared to normal and non-lesional psoriatic skin was reported by Sangeetha et al. [18] and Harvima et al. [19]. They also found that the majority of mast cells in psoriatic lesions were spindly and degranulated. Similarly, in our study most of the spindled mast cells were retrieved in the deep dermis of psoriatic skin lesions.

We also detected a significant increase in the number of lymphatic vessels in psoriatic skin biopsies in na przebieg limfangiogenezy niż inne rodzaje komórek zapalnych. Pojedyncza zmiana jednostkowa w komórkach tucznych może odpowiadać za 1369 zmian jednostkowych w naczyniach limfatycznych. Dla porównania - pojedyncza zmiana jednostkowa w innych komórkach zapalnych może wyjaśniać zaledwie 0,099 zmiany jednostkowej w naczyniach limfatycznych (tab. 2).

Na wykresie rozrzutu przedstawiającym dodatnią korelację liniową między średnią liczbą komórek tucznych a średnią liczbą naczyń limfatycznych stwierdzono dwie wartości odstające. Pierwsza z nich dotyczyła przypadku, w którym wykazano największą liczbę naczyń limfatycznych (32 wpw), ale umiarkowaną liczbę komórek tucznych (10 wpw). W tej próbce stwierdzono jednak najwyższą liczbę komórek zapalnych wybarwionych (-) metodą Giemsy spośród analizowanych przypadków. Drugi wynik odstający dotyczył przypadku, w którym odnotowano dużą liczbę komórek tucznych (15 wpw) i niewielką liczbę naczyń limfatycznych (8 wpw), natomiast naczynia miały największą średnicę spośród wszystkich analizowanych w naszym badaniu (0,25 mm) (ryc. 4). 


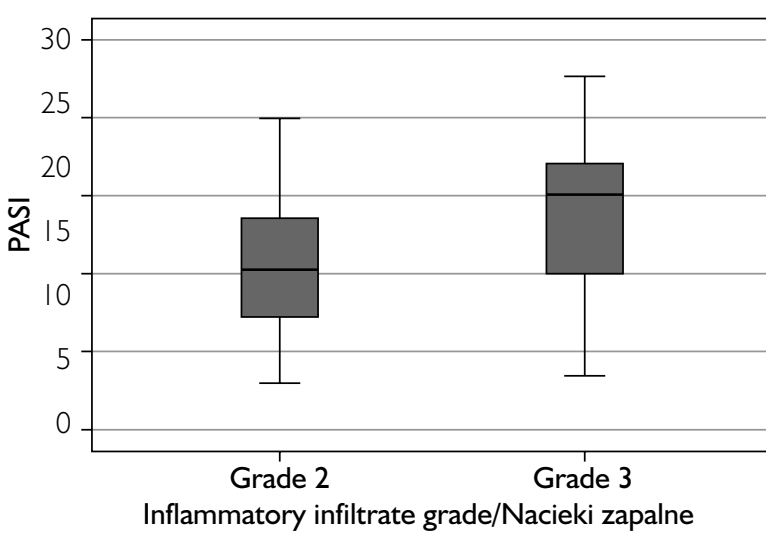

Figure 3. Box blot showing the relationship between grade of inflammation and PASI score in the studied cases of psoriasis

Rycina 3. Wykres pudełkowy przedstawiający zależność między nasileniem stanu zapalnego a wartością wskaźnika PASI w badanych przypadkach łuszczycy

comparison to normal skin. Similarly, Výbohová et al. [20] Fiedler et al. [21] and Töyry et al. [16] reported that the lymphatic bed is enlarged more in psoriatic skin than in healthy skin. In our study we used D2-40 for highlighting lymphatic vessels as it is reported to be a specific and a commercially available immunohistochemical marker for tracing the lymphatic vessels. Evangelia Moustou et al. reported that this marker is overexpressed in psoriatic skin, and is not reduced significantly after treatment, which may be due to a delay in lymphatic remodeling [22].

In our study, we confirmed that not only the number of lymphatic vessels increases in psoriatic skin lesions, but also the vessel diameter, which reflects increasing lymphatic surface area. This was in accord with Henno et al., who observed greater density and surface area of lymphatic vessels in psoriatic lesions than in skin from healthy volunteers [23]. In the study conducted by Výbohová et al. the lymphatic vessel area was 2.6 times greater in psoriatic than healthy skin [24]. Increased lymphatic vessel area is usually associated with dilated, more permeable lymphatic vessels and greater delivery of inflammatory mediators. Meier et al. highlighted the increased permeabil-

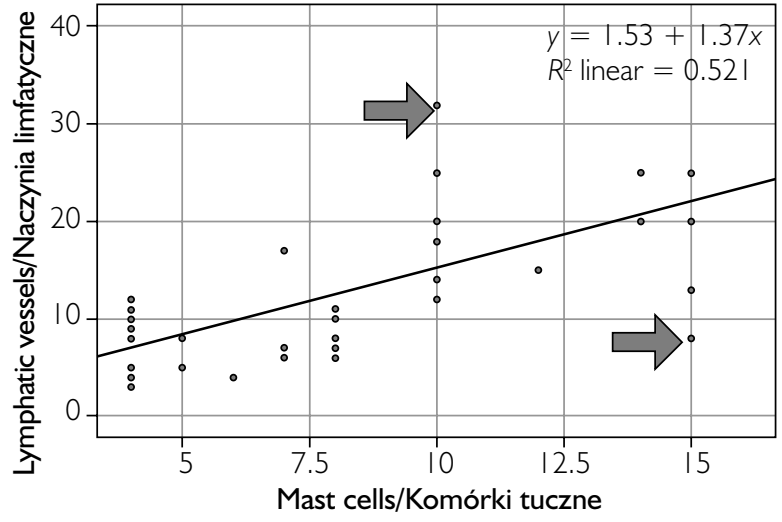

Figure 4. Scatter diagram showing the positive linear correlation between the mean number of mast cells and the mean number of lymphatic vessels. The two outliers are indicated by arrows

Rycina 4. Wykres rozrzutu obrazujący dodatnią korelację liniową między średnią liczbą komórek tucznych a średnią liczbą naczyń limfatycznych. Dwie wartości odstające zaznaczono strzałkami

\section{OMÓWIENIE}

Naczynia limfatyczne biorą udział w patogenezie przewlekłych zapalnych chorób skóry, w tym łuszczycy [14]. Limfangiogeneza w przebiegu łuszczycy jest procesem złożonym i wieloczynnikowym, w którym bierze udział kilka typów komórek, m.in. komórki tuczne. Środowisko zapalne, na które składają się makrofagi, limfocyty i neutrofile, również ma pewien wpływ na proces limfangiogenezy [15-17].

W przeprowadzonym przez nas badaniu średnia liczba komórek tucznych wybarwionych (+) metodą Giemsy była znamiennie wyższa w łuszczycowych zmianach skórnych niż w zdrowej skórze. Wzrost liczby komórek tucznych w warstwie powierzchownej skóry właściwej objętej zmianami łuszczycowymi (w porównaniu ze skórą zdrową oraz skórą łuszczycową poza obszarem zmian) opisali w swoich pracach Sangeetha i wsp. [18] oraz Harvima i wsp. [19]. Badacze ci stwierdzili również, że większość komórek tucznych w zmianach łuszczycowych ma postać wrzecionowatą i jest pozbawiona ziarnistości. Podobnych obserwacji dokonano w naszym badaniu. Większość wrzecionowatych komórek tucznych zidentyfikowano w warstwie głębokiej skóry właściwej w obrębie zmian łuszczycowych.

Table I. Univariate and multivariate analysis for parameters affecting number of lymphatic vessels

Tabela I. Analiza jednowymiarowa i wielowymiarowa parametrów wpływających na liczbę naczyń limfatycznych

\begin{tabular}{|c|c|c|c|c|}
\hline \multirow{2}{*}{$\begin{array}{l}\text { Number of lymphatic vessels/Liczba } \\
\text { naczyń limfatycznych }\end{array}$} & \multicolumn{2}{|c|}{ Univariate/Jednowymiarowa } & \multicolumn{2}{|c|}{ Multivariate/Wielowymiarowa } \\
\hline & OR $(95 \% \mathrm{Cl})$ & $P$-value/Wartość $P$ & OR $(95 \% \mathrm{Cl})$ & $P$-value/Wartość $p$ \\
\hline $\begin{array}{l}\text { No. of mast cells/Liczba komórek } \\
\text { tucznych }\end{array}$ & $1.369(0.988-1.75)$ & $<0.001$ & $0.407(-0.243-1.05)$ & 0.214 \\
\hline $\begin{array}{l}\text { Number of inflammatory cells other } \\
\text { than mast cells/ Liczba komórek } \\
\text { zapalnych innych niż komórki tuczne }\end{array}$ & $0.099(0.087-0.110)$ & $<0.001$ & $0.009(-0.562-0.580)$ & 0.974 \\
\hline $\begin{array}{l}\text { Total number of cells/Całkowita liczba } \\
\text { komórek }\end{array}$ & $0.096(0.085-0.107)$ & $<0.001$ & $0.073(-0.499-0.645)$ & 0.798 \\
\hline
\end{tabular}


ity of the lymphatics in psoriatic plaques and concluded that lymphatics change in psoriasis, not only morphologically but also functionally [25].

A significant positive correlation was detected in our study between the mean number of mast cells and lymphatic vessels. In their study, Detoraki et al. explained this significant correlation; they reported that mast cells are a source of lymphangiogenic factors VEGF-C and VEGF-D. In addition, they found that mast cells express both VEGF receptors 1 and 2 . Thus mast cells act as sources and targets of VEGFs [8].

In our study, we observed a significant positive correlation between Giemsa -ve inflammatory cells and the mean number of lymphatic vessels. This of course can be explained by the role of inflammatory cells in secreting lymphangiogenic factors. Similar results were reported in the literature $[15,17,24]$ Granata et al. highlighted the importance of macrophages in the synthesis of VEGF-C and VEGF-D that stimulate lymphangiogenesis [15]. Tan et al. reported that neutrophils may be involved in the organization of lymphangiogenesis during inflammation through modulation of VEGF-A bioavailability and bioactivity and, to a lesser extent, by secreting VEGF-D [17]. In our study, no significant correlation was detected between the size of lymphatic vessels and the mean number of mast cells or other inflammatory cells. This may be because the diameter measured in our study was the mean vessel size, not the total surface area, which requires a more complicated image analyzing system. Výbohová reported a significant positive correlation between inflammatory cellular infiltration area and the lymphatic vessel area [24].

The significant positive correlation between inflammatory cells and number of lymphatic vessels that was detected in our study and other reported studies may explain the distribution of inflammatory cells and lymphatic vessels in psoriasis [16, 20, 23]. Lymphatic vessels are found more in the upper parts of the papillary dermis closer to the site of inflammation in the diseased skin.

A multiple logistic regression model was built in our study, to include lymphatic vessels, and other significant variables to trace the independent influencers of lymphangiogenesis. None of those variables emerged as an independent denominator. However, a simple logistic regression model revealed that mast cells have a slightly stronger influence in guiding lymphangiogenesis than other inflammatory cells.

In the scatter diagram representing the linear positive correlation between the mean number of mast cells and the lymphatic vessels, two outliers were spotted; the first one was for a case having the highest number of lymphatic vessels but with few mast cells. Reviewing the number of inflammatory cells in this case, it emerged as the highest number encountered
Wykazano również znamienny wzrost liczby naczyń limfatycznych w materiale biopsyjnym pobranym ze skóry ze zmianami łuszczycowymi w porównaniu ze skórą zdrową. Vybohová i wsp. [20], Fiedler i wsp. [21] oraz Töyry i wsp. [16] zaobserwowali, że łożysko naczyń limfatycznych jest liczniejsze w skórze łuszczycowej w porównaniu ze skórą zdrową. W naszym badaniu do wizualizacji naczyń limfatycznych wykorzystano przeciwciało D2-40, ponieważ jest to swoisty i dostępny komercyjnie marker immunohistochemiczny umożliwiający identyfikację naczyń limfatycznych. W pracy Moustou i wsp. stwierdzono, że marker ten ulega nadekspresji w skórze objętej łuszczycą i nie podlega znamiennej redukcji po leczeniu, co może być wywołane opóźnieniem w przebudowie układu limfatycznego [22].

Przeprowadzone przez nas badanie wykazało nie tylko wzrost liczby naczyń limfatycznych w zmianach łuszczycowych, lecz także zwiększenie średnicy naczyń, czyli wzrost powierzchni limfatycznej. Wynik ten jest zgodny z obserwacjami przedstawionymi w pracy Henno i wsp., w której wskazano na zwiększoną gęstość i powierzchnię naczyń limfatycznych w zmianach łuszczycowych w porównaniu ze skórą zdrowych ochotników [23]. W badaniu Výbohovej i wsp. zaobserwowano, że powierzchnia naczyń limfatycznych jest 2,6-krotnie większa w skórze łuszczycowej niż w skórze zdrowej [24]. Wzrost powierzchni naczyń limfatycznych zazwyczaj wiąże się z obecnością rozszerzonych naczyń limfatycznych o zwiększonej przepuszczalności oraz ze wzmożonym uwalnianiem mediatorów zapalnych. Meier i wsp. zwrócili uwagę na wzrost przepuszczalności naczyń limfatycznych w tarczkach łuszczycowych, wnioskując, że zmiany w naczyniach limfatycznych towarzyszące łuszczycy mają charakter nie tylko morfologiczny, lecz także funkcjonalny [25].

W naszym badaniu stwierdzono znamienną dodatnią korelację między średnią liczbą komórek tucznych i liczbą naczyń limfatycznych. W badaniu Detoraki i wsp. wyjaśniono tę znamienną zależność, wskazując, że komórki tuczne są źródłem czynników limfangiogennych VEGF-C i VEGF-D. Badacze potwierdzili także ekspresję receptorów VEGF 1 i 2 w komórkach tucznych, co oznacza, że komórki tuczne działają zarówno jako źródła, jak i miejsca docelowe dla czynników VEGF [8].

W przeprowadzonym badaniu odnotowaliśmy znaczącą dodatnią korelację między komórkami zapalnymi wybarwionymi (-) metodą Giemsy a średnią liczbą naczyń limfatycznych. Można to wyjaśnić wpływem komórek zapalnych na wydzielanie czynników limfangiogennych. Podobne obserwacje można znaleźć w piśmiennictwie $[15,17,24]$. Granata i wsp. wskazali na rolę makrofagów w syntezie czynników VEGF-C i VEGF-D, które pobudzają limfangiogenezę [15]. Tan i wsp. zaobserwowali, że neutrofile mogą mieć swój udział w przebiegu limfangiogenezy w procesie zapalnym poprzez modulowanie biodostępności i bioaktywności VEGF- 
in our study. This may confirm the postulated conclusion that, although mast cells take the upper hand in lymphangiogenesis, this role may be overtaken in some cases by the role of other inflammatory cells.

The other outlier was for a case with high number of mast cells and dense inflammation but with few lymphatic vessels. Here the role of lymphatic vessel size and surface area emerged as an important influencer. This case expressed the largest diameter of lymphatic vessels encountered in our study. Although not significant in our study, the relation between lymphatic vessel diameter and inflammatory cells including the mast cells should be widely studied.

Clinically, PASI score in the studied cases significantly correlated with the grade of inflammation but not with other studied variables including lymphatic vessels and mast cells. In most of the reported literature, the role of lymphangiogenesis is still considered as a double weapon in chronic inflammatory diseases. Some have reported that lymphatic vessels are considered as a vehicle to transfer inflammatory cells with secretion of more mediators that exaggerate the severity of the disease [26], while others have reported that the stimulation of lymphangiogenesis by VEGF-C inhibits chronic skin inflammation [6]. In spite of this discrepancy, it was clearly highlighted that modulation of lymphatics could be a new strategy for the treatment of chronic inflammatory skin diseases [6].

\section{CONCLUSIONS}

Mast cells and other inflammatory cells significantly and synergistically act in regulating lymphangiogenesis in psoriatic lesions, with slightly higher participation of mast cells. Although lymphatic vessels are significantly higher in psoriatic lesions than in normal skin, the clinical effect of lymphangiogenesis in psoriasis is not clear and further studies are still needed to verify its role.

\section{CONFLICT OF INTEREST}

The authors declare no conflict of interest.
-A oraz w mniejszym stopniu poprzez wydzielanie VEGF-D [17]. Nasze badanie nie potwierdziło znamiennej korelacji między wielkością naczyń limfatycznych a średnią liczbą komórek tucznych ani innych komórek zapalnych. Być może wynik ten jest efektem schematu badania, w którym średnią wielkość naczynia określano na podstawie jego średnicy, a nie całkowitej powierzchni, co wymagałoby bardziej skomplikowanego systemu analizy obrazu. Výbohová w swojej pracy wykazała znamienną dodatnią korelację pomiędzy obszarem objętym naciekiem z komórek zapalnych i powierzchnią naczyń limfatycznych [24].

Znamienna dodatnia korelacja pomiędzy liczbą komórek zapalnych i liczbą naczyń limfatycznych stwierdzona w naszym badaniu, a także w innych, może wyjaśniać rozmieszczenie komórek zapalnych i naczyń limfatycznych w zmianach łuszczycowych [16, 20, 23]. Większa liczba naczyń limfatycznych występuje w górnej części warstwy brodawkowatej skóry właściwej, tj. bliżej obszaru objętego stanem zapalnym.

W przeprowadzonym przez nas badaniu zastosowano model wielokrotnej regresji logistycznej uwzględniający naczynia limfatyczne i inne istotne zmienne w celu identyfikacji niezależnych czynników wpływających na limfangiogenezę. Żadna z wymienionych zmiennych nie okazała się jednak niezależnym czynnikiem. W modelu jednowymiarowej regresji logistycznej wykazano jednak, że komórki tuczne mają nieco większy wpływ na przebieg limfangiogenezy niż inne rodzaje komórek zapalnych.

Na wykresie rozrzutu przedstawiającym dodatnią liniową korelację między średnią liczbą komórek tucznych i naczyń limfatycznych zaobserwowano dwie wartości odstające. Pierwsza z nich dotyczyła przypadku, w którym stwierdzono największą liczbę naczyń limfatycznych, ale niewielką liczbę komórek tucznych. Analiza liczby komórek zapalnych ujawniła, że jest ona największa w całym badaniu. Może to potwierdzać postulowany wniosek, że choć komórki tuczne odgrywają dominującą rolę w limfangiogenezie, w niektórych przypadkach większe znaczenie mają inne rodzaje komórek zapalnych.

Druga wartość odstająca dotyczyła przypadku, w którym wykryto dużą liczbę komórek tucznych i nasilony stan zapalny przy niewielkiej liczbie naczyń limfatycznych. W tym przypadku istotnymi czynnikami wpływającymi okazały się wielkość i powierzchnia naczyń limfatycznych. Stwierdzono największą średnicę naczyń limfatycznych spośród wszystkich analizowanych przypadków. Pomimo braku znamienności w przeprowadzonym przez nas badaniu zależność między średnicą naczyń limfatycznych a obecnością komórek zapalnych (m.in. komórek tucznych) powinna być analizowana $\mathrm{w}$ kolejnych badaniach.

Z perspektywy klinicznej wskaźnik PASI w badanych przypadkach wykazywał znamienną korelację z nasile- 
niem zapalenia, ale nie z innymi analizowanymi zmiennymi, m.in. obecnością naczyń limfatycznych i komórek tucznych. W większości dostępnych doniesień literaturowych limfangiogeneza jest opisywana jako „broń obosieczna” w przewlekłych chorobach zapalnych. W niektórych pracach naczynia limfatyczne są uważane za nośnik komórek zapalnych, co wiąże się z wydzielaniem większej ilości mediatorów zwiększających nasilenie choroby [26]. Inni badacze twierdzą natomiast, że pobudzanie limfangiogenezy przez czynnik VEGF-C prowadzi do zahamowania przewlekłego zapalenia skóry [6]. Mimo tej rozbieżności jednoznacznie podkreślono, że modulowanie układu chłonnego może stanowić nową strategię w leczeniu przewlekłych zapalnych chorób skóry [6].

\section{WNIOSKI}

Komórki tuczne i inne komórki zapalne wywierają znamienny oraz synergistyczny wpływ na regulację limfangiogenezy w zmianach łuszczycowych, przy czym nieznacznie większą rolę odgrywają komórki tuczne. Chociaż liczba naczyń limfatycznych jest znamiennie większa w zmianach łuszczycowych niż w zdrowej skórze, skutki kliniczne limfangiogenezy w łuszczycy nie zostały dotąd dokładnie poznane. Niezbędne są dalsze badania, aby zweryfikować rolę tego procesu.

\section{KONFLIKT INTERESÓW}

Autorzy nie zgłaszają konfliktu interesów.

\section{References}

\section{Piśmiennictwo}

1. Gibbs S.: Skin disease and socioeconomic conditions in rural Africa: Tanzania. Int J Dermatol 1996, 35, $633-639$.

2. Danielsen K., Olsen A.O., Wilsgaard T., Furberg A.S.: Is the prevalence of psoriasis increasing? A 30-year follow-up of a population-based cohort. Br J Dermatol 2013, 168, 1303-1310.

3. Schön M.P.: Adaptive and innate immunity in psoriasis and other inflammatory disorders. Front Immunol $2019,10,1764$.

4. Griffiths C.E., Barker J.N.: Pathogenesis and clinical features of psoriasis. Lancet 2007, 370, $263-271$.

5. Henno A., Blacher S., Lambert C.A., Deroanne C., Noel A., Lapiere C., et al.: Histological and transcriptional study of angiogenesis and lymphangiogenesis in uninvolved skin, acute pinpoint lesions and established psoriasis plaques: an approach of vascular development chronology in psoriasis. J Dermatol Sci 2010, 57, 162-169.

6. Huggenberger R., Ullmann S., Proulx S.T., Pytowski B., Alitalo K., Detmar M.: Stimulation of lymphangiogenesis via VEGFR-3 inhibits chronic skin inflammation. J Exp Med 2010, 207, 2255-2269.

7. Harvima I.T., Nilsson G., Suttle M., Naukkarinen A.: Is there a role for mast cells in psoriasis? Arch Dermatol Res 2008, 300, 461-478.

8. Detoraki A., Granata F., Staibano S., Rossi F.W., Marone G., Genovese A.: Angiogenesis and lymphangiogenesis in bronchial asthma. Allergy 2010, 65, 946-958.

9. Varricchi G., Granata F., Loffredo S., Genovese A., Marone G.: Angiogenesis and lymphangiogenesis in inflammatory skin disorders. J Am Acad Dermatol 2015, 73, 144-153.

10. Moorchung N., Khullar J.S., Mani N.S., Chatterjee M., Vasudevan B., Tripathi T.: A study of various histopathological features and their relevance in pathogenesis of psoriasis. Indian J Dermatol 2013, 58, 294-298.

11. Carson F.L., Freida L., Hladik C.: Histotechnology: a Self-instructional Text. $4^{\text {th }}$ ed. ASCP Press, Chicago, 2015, 130-131.

12. Dzulkifli F.A., Mashor M.Y., Jaafar H.: An overview of recent counting methods for Ki67 IHC staining. J Biomed Clin Sci 2018, 3, 10-17.

13. Gresta L.T., Júnior I.A., Cabral M.M.: Microvessel density quantification in gastric cancer: comparing methods for standard measures. J Cancer Sci Ther 2014, 6, 401-405.

14. Huggenberger R., Detmar M.: The cutaneous vascular system in chronic skin inflammation. J Invest Dermatol 2011, 15 , 24-32. 
15. Granata F., Frattini A., Loffredo S., Staiano R.I., Petraroli A., Ribatti D., et al.: Production of vascular endothelial growth factors from human lung macrophages induced by group IIA and group X secreted phospholipases A2. J Immunol 2010, 184, 5232-5241.

16. Töyry S., Fräki J.E., Tammi R.: Mast cell density in psoriatic skin. The effect of PUVA and corticosteroid therapy. Arch Dermatol Res 1988, 280, 282-285.

17. Tan K.W., Chong S.Z., Wong F.H.S., Evrard M., Tan S.M., Keeble J.O., et al.: Neutrophils contribute to inflammatory lymphangiogenesis by increasing VEGF-A bioavailability and secreting VEGF-D. Blood 2013, 122, 3666-3677.

18. Sangeetha R.S., Jayaprakash H.T.: Pathogenesis of psoriasis: a new angle with mast cell. Indian J Pathol Oncol 2016, 3, 617-621.

19. Harvima I.T., Naukkarinen A., Harvima R.J., Horsmanheimo M.: Enzyme- and immunohistochemical localization of mast cell tryptase in psoriatic skin. Arch Dermatol Res 1989, 281, 387-391.

20. Vybohová D., Mellováa Y., Adamicováb K., Adamkovc M., Heskováa G.: Quantitative comparison of angiogenesis and lymphangiogenesis in cutaneous lichen planus and psoriasis: immunohistochemical assessment. Acta Histochem 2015, 117, $20-28$.

21. Fiedler E., Helmbold P., Marsch W.C.: Increased vessel density in psoriasis: involvement of lymphatic vessels in the papillary dermis. Br J Dermatol 2008, 159, 231-266.

22. Moustou A.E., Alexandrou P., Stratigos A.J., Giannopoulou I., Vergou T., Katsambas A., et al.: Expression of lymphatic markers and lymphatic growth factors in psoriasis before and after anti-TNF treatment. An Bras Dermatol 2014, 89, 891-897.

23. Henno A., Blacher S., Lambert C., Colige A., Seidel L., Noe A., et al.: Altered expression of angiogenesis and lymphangiogenesis markers in the uninvolved skin of plaque-type psoriasis. Br J Dermatol 2009, 160, 581-590.

24. Výbohová D., Adamicová K., Mellová Y., Hešková G.: Microvascular changes in relation to inflammation and epidermal hyperplasia in chronic cutaneous lesions of psoriasis vulgaris. Histol Histopathol 2017, 32, 461-470.

25. Meier T.O., Kovacicova L., Huggenberger R., Navarini A.A., Gitzelmann G., Amann-Vesti B.R.: Increased permeability of cutaneous lymphatic capillaries and enhanced blood flow in psoriatic plaques. Dermatology 2013, 227, 118-125.

26. Liao S., Von der Weid P.V.: Inflammation-induced lymphangiogenesis and lymphatic dysfunction. Angiogenesis 2014, 17, 325-334.

Received: 2.02 .2020

Accepted: 31.08 .2020

Otrzymano: $2.02 .2020 \mathrm{r}$.

Zaakceptowano: $31.08 .2020 \mathrm{r}$.

How to cite this article

Abdel-Bary A., Abdel-Bary A.: The role of mast cells and other inflammatory cells in induction of lymphangiogenesis in psoriasis. Dermatol Rev/Przegl Dermatol 2020, 107, 495-507, DOI: https://doi.org/10.5114/dr.2020.103886 